BIOFARM

Jurnal Ilmiah Pertanian

ISSN Print: 0216-5430; ISSN Online: 2301-6442

Vol. 14, No. 1, April 2018

\title{
Pengaruh Lama Perendaman Rootone F dan Dosis Pupuk Kandang Sapi terhadap Pertumbuhan Stek Nilam (Pogostemon cablin BENTH)
}

\section{The Effect of Soaking Time of Rootone F And Dose Cowmanure on The Growth of Cuttings Patcouli (Pogostemon cablin BENTH)}

\author{
Nurahim ${ }^{1 *}$ dan Ari Handriatni ${ }^{2}$ \\ ${ }^{1}$ Perum Perhutani KPH Pekalongan Timur \\ ${ }^{2}$ Program Studi Agroteknologi, Fakultas Pertanian, Universitas Pekalongan \\ *Korespondensi Penulis: nurahimtanpkt|@gmail.com
}

\begin{abstract}
ABSTRAK
Penelitian bertujuan untuk mengetahui lama perendaman Rootone $\mathrm{F}$ dan dosis pupuk kandang sapi yang optimum serta interaksinya terhadap pertumbuhan tanaman nilam. Penelitian dilaksanakan di Kelurahan Medono, Pekalongan Barat, Pekalongan. Penelitian dilaksanakan selama bulan yaitu bulan Januari sampai April 2014. Rancangan percobaan yang digunakan adalah Rancangan Acak Kelompok (RAK) dengan factorial 3 × 4 . Faktor pertama lama perendaman Rootone $F$ terdiri atas 3 taraf (lama perendaman 1 jam, 2 jam dan 3 jam). Faktor kedua dosis pupuk kandang sapi terdiri atas 4 taraf $(0$ ton/ha, 10 ton/ha, 20 ton/ha dan 30 ton/ha). Setiap perlakuan diulang tiga kali. Variabel yang diamati meliputi jumlah akar, panjang akar terpanjang, bobot basah akar, bobot kering akar, jumlah daun, diameter batang, tinggi tanaman, bobot basah brangkasan, bobot kering brangkasan dan persentase tumbuh. Hasil penelitian menunjukkan bahwa lama perendaman berpengaruh sangat nyata terhadap jumlah akar, panjang akar terpanjang, bobot basah akar, bobot kering akar, diameter batang, bobot basah brangkasan, dan bobot kering brangkasan, sedangkan variabel jumlah daun dan tinggi tanaman berbeda nyata. Lama perendaman 3 jam (L3) memberikan hasil yang terbaik. Dosis pupuk kandang berpengaruh sangat nyata terhadap semua variabel. Dosis pupuk kandang sapi terbaik 30 ton/ha. Interaksi antara lama perendaman Rootone F dengan dosis pupuk kandang sapi berpengaruh sangat nyata terhadap semua variabel yang diamati. Interaksi terbaik pada lama perendaman 3 jam dengan dosis pupuk 30 ton/ha (L3D3).
\end{abstract}

Kata kunci: stek nilam, Rootone F, dosis pupuk kandang

\section{ABSTRACT}

This research were aimed to determine the effect of the soaking time Rootone $F$ and dose optimum cow manure as well as its interaction with patchouli plant growth. The Research was conducted in the Medono village, District West Pekalongan, Pekalongan. The research carried out for 4 months ie January to April 2014. The experimental design used was a randomized block design (RBD) with factorial $3 \times 4$. The first factor soaking time Rootone F consists of 3 levels (soaking time 1 hour, 2 hours and 3 hours). The second factor dosage of cow manure consists of 4 levels ( 0 ton / ha, 10 tons / ha, 20 tons / ha and 30 tons / ha). Each treatment was replicated three times. Observed variables include the number of roots, the longest root length, weight of root gresh, weight of root dry, number of leaves, diameter of stem, height of plant, weight of stover wet, weight of stover dry and percentage grow. The results showed that the soaking time very significant effect on the number of roots, the longest root length, weight of root gresh, weight of root dry, diameter of stem, weight of stover wet, and weight of stover dry except leaf number of leaves and height of plant. 3 hours soaking time (L3) give the best results. Dosage manure very significant effect on all variables. Dosage best cow manure 30 tons / ha. Interaction between soaking time Rootone $F$ with a dose of cow manure was highly significant for all the variables observed except percentages grow. Interaction best in 3 hours soaking time with fertilizer dose of 30 tonnes / ha (L3D3).

Keywords: cuttings patchouli, Rootone F, manure dosage

\section{PENDAHULUAN}

Nilam (Pogostemon cablin Benth) merupakan tanaman perkebunan yang berbentuk semak namun memiliki prospek ekonomi yang sangat cerah karena merupakan komoditas ekspor non migas (Rukmana, 2004). Indonesia merupakan salah satu negara penghasil minyak atsiri yang cukup penting di dunia, kendati kontribusi ekspor minyak nilam relatif kecil terhadap devisa negara, namun perkembangan volume dan nilai ekspor komoditi ini meningkat cukup tajam setiap tahunnya, bahkan akhir-akhir ini harga jual ekspor di pasaran dunia mencapai US \$ 1.000 per kg. Prospek ekspor komoditi ini pada masa yang akan datang juga masih 
cukup besar, seiring dengan semakin tingginya permintaan terhadap parfum/kosmetika, trend mode dan belum berkembangnya barang subsitusi essential oil yang bersifat pengikat (fiksasi) dalam industri parfum/ kosmetika (Santoso, 1990).

Perbanyakan tanaman nilam kebanyakan dilakukan secara vegetatif (stek), karena tanaman nilam jarang atau bahkan tidak berbunga. Selain dapat diperoleh bibit dengan kualitas yang sama dengan induknya, juga dapat diperoleh bibit dalam jumlah yang besar dan dalam jangka waktu yang relatif singkat. Untuk mempercepat pertumbuhan akar stek nilam dapat dipacu dengan pemberian zat pengatur tumbuh. Lama perendaman stek nilam dalam larutan Rootone F menyebabkan aktifitas pembelahan sel meningkat, hal ini diduga akibat serapan/ absorbsi dari kandungan Rootone F sebagai hormon auksin buatan yang dapat merangsang pertumbuhan, terutama bagian meristem dititik tunas dan akar (Rotinsuluh dan Johan, 2008).

Menurut Kusumo (1994), lamanya perendaman stek tergantung pada macam stek dan macam tanaman sebagai bahan stek. Untuk stek pada tanaman yang berdaun dan berkayu perendaman dilakukan selama 1 sampai 2 jam dalam larutan yang berkonsentrasi $100 \mathrm{ppm}$, atau 10 sampai 24 jam didalam larutan yang konsentrasinya $5 \mathrm{ppm}$. Lama perendaman juga tergantung pada kepekatan larutan. Kepekatan yang tinggi sekitar 1000 ppm, maka waktu perendaman akan lebih cepat, namun pada kepekatan yang rendah waktu perendaman akan lebih lama.

Untuk memperbaiki pertumbuhan tanaman dapat dilakukan dengan pemberian pupuk kandang. Pupuk kandang merupakan kotoran padat dan cair dari hewan yang tercampur dengan sisa-sisa pakan dan alas kandang, sehingga kandungannya terdiri dari nitrogen, asam fosfat, kalium dan hampir semua unsur hara makro dan mikro, dengan demikian pupuk kandang berperan dalam memelihara keseimbangan hara dalam tanah (Sarief, 1989). Pupuk yang digunakan adalah pupuk kandang sapi. Menurut Asnani (2008) bahwa penggunaan dosis pupuk kandang pada tanaman buncis sebesar 10 ton/ha dan 20 ton/ha ternyata belum mendapatkan titik optimum, namun masih menunjukkan angka yang linear.

Penelitian ini bertujuan untuk mengetahui pengaruh lama perendaman zat pengatur tumbuh Rootone F yang optimal terhadap pertumbuhan stek nilam, mengetahui pengaruh dosis pupuk kandang sapi yang optimal untuk memperbaiki pertumbuhan stek nilam, serta mengetahui pengaruh interaksi antara lama perendaman zat pengatur tumbuh Rootone $\mathrm{F}$ dan dosis pupuk kandang sapi yang mampu memperbaiki pertumbuhan stak nilam.

\section{BAHAN DAN METODE}

Penelitian ini telah dilaksanakan di Kelurahan Medono, Jln. Yudha Bakti No. 77 Asrama Polisi Hutan (Polhut) KPH Pekalongan Timur yang masuk dalam wilayah Kecamatan Pekalongan Barat, Kota Pekalongan, dengan ketinggian tempat sekitar 3 meter di atas permukaan laut. Penelitian dilaksanakan selama 4 bulan yaitu dimulai bulan Januari sampai bulan April 2014. Rancangan yang digunakan dalam penelitian ini adalah RAK (Rancangan Acak Kelompok). Penelitian ini merupakan percobaan faktorial yang terdiri atas 2 faktor. Faktor pertama adalah lama perendaman Rootone F dan faktor kedua dosis pupuk kandang sapi. Lama perendaman Rootone $\mathrm{F}$ terdiri atas $\mathrm{L} 1$ = lama perendaman $1 \mathrm{jam}, \mathrm{L} 2$ = lama perendaman 2 jam, L3 = lama perendaman $3 \mathrm{jam}$. Dosis pupuk kandang sapi terdiri atas D0 (tanpa pemberian pupuk kandang /kontrol), D1 (dosis pupuk kandang 10 ton/ha), D2 (dosis pupuk kandang 20 ton/ha), D3 (dosis pupuk kandang $30 \mathrm{~kg} / \mathrm{ha}$ ), perlakuan diulang tiga kali.

Variabel yang diamati meliputi jumlah akar, panjang akar terpanjang, bobot basah akar, bobot kering akar, jumlah daun, diameter batang, tinggi tanaman, bobot basah brangkasan, bobot kering brangkasan, dan persentase tumbuh. 
Data yang diperoleh dianalisis dengan Uji F. Jika antara faktor yang dicoba terdapat perbedaaan nyata maka analisis dilanjutkan dengan Uji BNT, untuk lama perendaman Rootone $F$ dilanjutkan dengan uji kontras orthogonal sedangkan dosis pupuk kandang sapi diuji menggunakan regresi.

\section{HASIL DAN PEMBAHASAN}

\section{Lama perendaman Rootone $F$}

Hasil penelitian menunjukkan bahwa perlakuan lama perendaman Rootone $\mathrm{F}$ berbeda sangat nyata terhadap semua variabel pengamatan. Hasil tertinggi jumlah akar, panjang akar terpanjang, bobot basah akar, bobot kering akar, jumlah daun, diameter batang, tinggi tanaman, bobot basah brangkasan dan bobot kering brangkasan dicapai pada lama perendaman 3 jam (L3) dengan jumlah akar 36,73 buah, panjang akar terpanjang $36,75 \mathrm{~cm}$, bobot basah akar 18,63 $\mathrm{g}$, bobot kering akar 2,83 g, jumlah daun 40,35 helai, diameter batang $62,93 \mathrm{~mm}$, tinggi tanaman $58,93 \mathrm{~cm}$, bobot basah brangkasan $63,91 \mathrm{~g}$, bobot kering brangkasan 12 , $39 \mathrm{~g}$.

Tabel 1. Angka Rata-rata dan Analisis Statistik Data Variabel Pengamatan Antara Lama Perendaman dan Dosis Pupuk Kandang.

\begin{tabular}{|c|c|c|c|c|c|}
\hline Perlakuan & $\begin{array}{l}\text { Jumlah akar } \\
\text { (buah) }\end{array}$ & $\begin{array}{l}\text { Panjang akar } \\
(\mathrm{cm})\end{array}$ & $\begin{array}{l}\text { Bobot basah } \\
\text { akar } \\
\text { (g) }\end{array}$ & $\begin{array}{l}\text { Bobot } \\
\text { kering akar } \\
\text { (g) }\end{array}$ & $\begin{array}{l}\text { Jumlah d } \\
\text { (helai) }\end{array}$ \\
\hline \multicolumn{6}{|l|}{ Lama perendaman } \\
\hline L1 = 1 jam & $33,35 \mathrm{a}$ & $29,13 \mathrm{a}$ & $13,38 \mathrm{a}$ & $2,17 \mathrm{a}$ & $35,58 \mathrm{a}$ \\
\hline $\mathrm{L} 2=2 \mathrm{jam}$ & $34,05 \mathrm{a}$ & $32,47 \mathrm{~b}$ & 16,7 & 2,4 & $38,18 \mathrm{a}$ \\
\hline L3 $=3 \mathrm{jam}$ & $36,73 \mathrm{~b}$ & $36,75 \mathrm{c}$ & $18,63 \mathrm{~b}$ & 2,8 & $40,35 \mathrm{~b}$ \\
\hline F Hitung & $5,73^{* *}$ & 44,59 ** & $9,91^{* *}$ & 8,3 & 3,98 * \\
\hline F Tabel $5 \%$ & 3,44 & 3,44 & 3,44 & 3,4 & 3,44 \\
\hline F Tabel $1 \%$ & 5,72 & 5,72 & 5,72 & 5,72 & 5,72 \\
\hline BNT $5 \%$ & 2,19 & 1,68 & 2,48 & 0,34 & 3,52 \\
\hline $\mathrm{KK}$ & $7,45 \%$ & $6,04 \%$ & $17,99 \%$ & $15,97 \%$ & $10,92 \%$ \\
\hline
\end{tabular}

\begin{tabular}{llllll}
\hline Dosis pupuk & & & & & \\
D0 $=0$ ton/ha & $31,09 \mathrm{a}$ & $31,82 \mathrm{a}$ & $10,38 \mathrm{a}$ & $1,60 \mathrm{a}$ & $17,02 \mathrm{a}$ \\
D1 $=10$ ton/ha & $32,62 \mathrm{a}$ & $32,04 \mathrm{a}$ & $13,73 \mathrm{~b}$ & $2,27 \mathrm{~b}$ & $26,31 \mathrm{~b}$ \\
D2 $=20$ ton/ha & $36,13 \mathrm{~b}$ & $32,24 \mathrm{a}$ & $18,92 \mathrm{c}$ & $2,47 \mathrm{~b}$ & $46,37 \mathrm{c}$ \\
D3 $=30$ ton/ha & $39,00 \mathrm{c}$ & $35,02 \mathrm{~b}$ & $21,97 \mathrm{~d}$ & $3,60 \mathrm{c}$ & $62,44 \mathrm{~d}$ \\
F Hitung & $17,022^{* *}$ & $5,18^{* *}$ & $28,29{ }^{* *}$ & $39,688^{* *}$ & $216,477^{* *}$ \\
F Tabel 5 \% & 3,05 & 3,05 & 3,05 & 3,05 & 3,05 \\
F Tabel 1\% & 4,82 & 4,82 & 4,82 & 4,82 & 4,82 \\
BNT 5\% & 2,53 & 1,94 & 2,86 & 0,39 & 4,06 \\
KK & $7,45 \%$ & $6,04 \%$ & $17,99 \%$ & $15,97 \%$ & $10,92 \%$ \\
\hline
\end{tabular}

Keterangan:

Angka-angka dalam kolom dan perlakuan yang diikuti dengan huruf yang sama menunjukkan tidak berbeda nyata berdasarkan Uji BNT pada taraf $5 \% .{ }^{* *}=$ berbeda sangat nyata, ${ }^{*}=$ berbeda nyata, $\mathrm{tn}=$ tidak berbeda nyata

Peningkatan jumlah akar, panjang akar terpanjang, bobot basah akar, bobot kering akar, jumlah daun, diameter batang, tinggi tanaman, bobot basah brangkasan, bobot kering brangkasan $\mathrm{Hal}$ ini disebabkan karena lama perendaman Rootone $F$ yang terlalu cepat kurang begitu aktif menggiatkan bahan stek untuk keluar akar. Rootone $F$ pada perlakuan lama perendaman yang tepat akan memberikan hasil yang baik. Hal ini dise- babkan oleh kandungan bahan aktif dalam Rootone-F yaitu Naphtalene acetamide (NAD) sebanyak 0,067\%, Methy-1Naphtelene acetic acid (MNAA) sebanyak 0,033\%, Methyle-1-Napthelene acetamide (MNDA) sebanyak 0,013\%, Indole-3-butyric acid (IBA) sebanyak 0,057\%. Bahan aktif tersebut akan mempengaruhi perubahan sel. Setiap hormon memiliki perbedaan sifat dalam pembelahan sel, namun secara kese- 
luruhan mengandung auksin yang berfungsi merangsang pertumbuhan akar (Suprianto dan Prakasa, 2011).

IBA yang diaplikasikan pada stek berada tetap ditempat pemberiannya, dan juga IBA berfungsi sebagai pengatur pem-besaran sel dan memicu pemanjangan sel di daerah belakang meristem ujung. Peman-jangan sel terjadi karena adanya proses pembelahan, pemanjangan dan pembesaran sel-sel baru yang terjadi pada meristem ujung sehingga terbentuk perakaran yang lebih panjang (Santoso, 2011). Semakin panjang akarnya, maka kemampuan menyerap air dan unsur hara dalam tanah lebih banyak (Kustina, 2000 dalam Anang dkk., 2013).

IBA, IAA dan NAA yang terkandung dalam Rootone $F$ yang berfungsi sebagai pengatur pembesaran sel dan memicu pemanjangan sel di daerah belakang maristem.

Pemanjangan sel terjadi karena adanya pro- ses pembelahan, pemanjangan dan pembesaran sel-sel baru yang terjadi pada meristem, sehingga bahan tanam yang ditanam bertambah tinggi (Santoso, 2011). IBA, IAA dan NAA yang terkandung dalam Rootone $F$ juga dapat menggiatkan pembentukan kalus dan akar yang berfungsi untuk penyerapan unsur hara yang dibutuhkan bagi kelangsungan hidup dan pertumbuhan stek tersebut seperti pertumbuhan organ- organ vegetatif yaitu tunas, daun dan sebagainya (Sudrajad dan Widodo, 2011). Semakin efektif penyerapan unsur hara dan fotosintesis maka pertumbuhan tanaman semakin cepat. Menurut Manurung (1987) dalam Sudrajad dan Widodo (2011), pengambilan auksin oleh tanaman dari media ke dalam jaringan tanaman berlangsung secara proporsional.

Tabel 2. Angka Rata-rata dan Analisis Statistik Data Variabel Pengamatan Antara Lama Perendaman dan Dosis Pupuk Kandang.

\begin{tabular}{|c|c|c|c|c|}
\hline Perlakuan & $\begin{array}{l}\text { Diameter } \\
\text { batang } \\
(\mathrm{mm})\end{array}$ & $\begin{array}{l}\text { Tinggi } \\
\text { tanaman } \\
(\mathrm{cm})\end{array}$ & $\begin{array}{l}\text { Bobot basah } \\
\text { brangkasan } \\
\text { (g) }\end{array}$ & $\begin{array}{l}\text { Bobot kering } \\
\text { brangkasan } \\
\text { (g) }\end{array}$ \\
\hline \multicolumn{5}{|c|}{ Lama perendaman L1 = } \\
\hline 1 jam & $57,31 \mathrm{a}$ & $55,80 \mathrm{a}$ & 54,68 a & $8,50 \mathrm{a}$ \\
\hline $\mathrm{L} 2=2 \mathrm{jam}$ & $60,45 \mathrm{~b}$ & $57,98 \mathrm{a}$ & $59,42 \mathrm{a}$ & $10,62 b$ \\
\hline $\mathrm{L} 3=3 \mathrm{jam}$ & $62,93 \mathrm{c}$ & $58,93 \mathrm{~b}$ & $63,91 \mathrm{~b}$ & $12,39 \mathrm{~b}$ \\
\hline F Hitung & 18,42 ** & 4,28 * & $6,61^{* *}$ & 7,94 ** \\
\hline F Tabel $5 \%$ & 3,44 & 3,44 & 3,44 & 3,44 \\
\hline F Tabel $1 \%$ & 5,72 & 5,72 & 5,72 & 5,72 \\
\hline BNT $5 \%$ & 1,93 & 2,27 & 5,27 & 2,03 \\
\hline KK & $3,78 \%$ & $4,66 \%$ & $10,49 \%$ & $22,78 \%$ \\
\hline \multicolumn{5}{|l|}{ Dosis pupuk } \\
\hline D0 $=0$ ton $/$ ha & $55,69 \mathrm{a}$ & $46,63 \mathrm{a}$ & $27,68 \mathrm{a}$ & $3,88 \mathrm{a}$ \\
\hline $\mathrm{D} 1=10$ ton $/ \mathrm{ha}$ & $57,82 \mathrm{a}$ & $50,44 \mathrm{~b}$ & $45,85 \mathrm{~b}$ & $7,01 \mathrm{~b}$ \\
\hline $\mathrm{D} 2=20$ ton $/ \mathrm{ha}$ & $62,38 \mathrm{~b}$ & $65,18 \mathrm{c}$ & $72,20 \mathrm{c}$ & $14,30 \mathrm{c}$ \\
\hline $\mathrm{D} 3=30 \mathrm{ton} / \mathrm{ha}$ & $65,03 \mathrm{c}$ & $68,02 \mathrm{~d}$ & $91,61 \mathrm{~d}$ & $16,82 \mathrm{~d}$ \\
\hline F Hitung & $31,36^{* *}$ & 140,56 ** & $185,27^{* *}$ & 57,90 ** \\
\hline F Tabel $5 \%$ & 3,05 & 3,05 & 3,05 & 3,05 \\
\hline F Tahel $1 \%$ & 4,82 & 4,82 & 4,82 & 4,82 \\
\hline F label $1 \%$ & 2,22 & 2,62 & 6,08 & 2,34 \\
\hline BNT $5 \%$ & $3,78 \%$ & $4,66 \%$ & $10,49 \%$ & $22,78 \%$ \\
\hline
\end{tabular}

Keterangan:

Angka-angka dalam kolom dan perlakuan yang diikuti dengan huruf yang sama menunjukkan tidak berbeda nyata berdasarkan Uji BNT pada taraf $5 \% .{ }^{* *}=$ berbeda sangat nyata, ${ }^{*}=$ berbeda nyata, tn $=$ tidak berbeda nyata 
Tabel 3. Angka Rata-rata Analisis Statistik dan Interaksi Antara Lama Perendaman dan Dosis Pupuk Kandang variabel pengamatan.

\begin{tabular}{llllll}
\hline $\begin{array}{l}\text { Kombinasi } \\
\text { Perlakuan }\end{array}$ & $\begin{array}{l}\text { Jumlah akar } \\
\text { (buah) }\end{array}$ & $\begin{array}{l}\text { Panjang akar } \\
\text { terpanjang } \\
\text { (cm) }\end{array}$ & $\begin{array}{l}\text { Bobot basah } \\
\text { akar }(\mathrm{g})\end{array}$ & $\begin{array}{l}\text { Bobot kering } \\
\text { akar }(\mathrm{g})\end{array}$ & $\begin{array}{l}\text { Jumlah daun } \\
\text { (helai) }\end{array}$ \\
\hline L1D0 & $28.53 \mathrm{a}$ & $26,87 \mathrm{a}$ & $8,02 \mathrm{a}$ & $1,29 \mathrm{a}$ & $14,40 \mathrm{a}$ \\
L1D1 & $31.53 \mathrm{a}$ & $28,87 \mathrm{a}$ & $11,94 \mathrm{a}$ & $2,26 \mathrm{~b}$ & $23,33 \mathrm{~b}$ \\
L1D2 & $34.40 \mathrm{~b}$ & $27,93 \mathrm{a}$ & $14,70 \mathrm{~b}$ & $1,89 \mathrm{a}$ & $44,30 \mathrm{c}$ \\
L1D3 & $38.93 \mathrm{c}$ & $32,87 \mathrm{~b}$ & $18,87 \mathrm{c}$ & $3,24 \mathrm{c}$ & $60,27 \mathrm{~d}$ \\
L2D0 & $31.93 \mathrm{a}$ & $33,47 \mathrm{~b}$ & $11,21 \mathrm{a}$ & $1,74 \mathrm{a}$ & $16,93 \mathrm{a}$ \\
L2D1 & $32.80 \mathrm{a}$ & $31,00 \mathrm{~b}$ & $13,79 \mathrm{~b}$ & $2,16 \mathrm{~b}$ & $27,53 \mathrm{~b}$ \\
L2D2 & $35.53 \mathrm{~b}$ & $31,40 \mathrm{~b}$ & $19,59 \mathrm{c}$ & $2,48 \mathrm{~b}$ & $45,00 \mathrm{c}$ \\
L2D3 & $35.93 \mathrm{c}$ & $34,00 \mathrm{~b}$ & $22,37 \mathrm{c}$ & $3,44 \mathrm{c}$ & $63,27 \mathrm{~d}$ \\
L3D0 & $32.80 \mathrm{a}$ & $35,13 \mathrm{c}$ & $11,92 \mathrm{a}$ & $1,77 \mathrm{a}$ & $19,73 \mathrm{a}$ \\
L3D1 & $33.53 \mathrm{~b}$ & $36,27 \mathrm{c}$ & $15,48 \mathrm{~b}$ & $2,39 \mathrm{~b}$ & $28,07 \mathrm{~b}$ \\
L3D2 & $38.47 \mathrm{c}$ & $37,40 \mathrm{c}$ & $22,45 \mathrm{c}$ & $3,13 \mathrm{c}$ & $49,80 \mathrm{c}$ \\
L3D3 & $42.13 \mathrm{~d}$ & $38,20 \mathrm{c}$ & $24,68 \mathrm{~d}$ & $4,12 \mathrm{~d}$ & $63,80 \mathrm{~d}$ \\
F Hitung & $10,85 * *$ & $5,59 * *$ & $14,88 * *$ & $5,75 * *$ & $4,74 * *$ \\
F Tabel 5 \% & 2,55 & 2,55 & 2,55 & 2,55 & 2,55 \\
F Tabel 1 \% & 3,76 & 3,76 & 3,76 & 3,76 & 3,76 \\
BNT 5 \% & 4,38 & 3,35 & 4,95 & 0,67 & 7,03 \\
KK & $7,45 \%$ & $6,04 \%$ & $17,99 \%$ & $15,97 \%$ & $10,92 \%$ \\
\hline Ke & & & &
\end{tabular}

Keterangan:

Angka-angka dalam kolom dan perlakuan yang diikuti dengan huruf yang sama menunjukkan tidak berbeda nyata berdasarkan Uji BNT pada taraf $5 \%$. ${ }^{* *}=$ berbeda sangat nyata, ${ }^{*}=$ berbeda nyata, tn $=$ tidak berbeda nyata.

\section{Dosis pupuk kandang sapi}

Hasil penelitian menunjukkan bahwa perlakuan dosis pupuk kandang sapi berpengaruh sangat nyata terhadap semua variabel pengamatan kecuali persentase tumbuh tidak beda nyata. Hasil tertinggi dari semua variabel kecuali persentase tumbuh dicapai pada dosis pupuk kandang sapi 30 ton/ha dengan jumlah akar 39 buah, panjang akar terpanjang $35,02 \mathrm{~cm}$, bobot basah akar 21,97 $\mathrm{g}$, bobot kering akar $3,60 \mathrm{~g}$, jumlah daun 62,44 , diameter batang $65,03 \mathrm{~mm}$, tinggi tanaman, $68,02 \mathrm{~cm}$, bobot basah brangkasan $91,61 \mathrm{~g}$, bobot kering brangkasan 16,82 g.

Dosis pupuk kandang sapi 30 ton/ ha memberikan respon pertumbuhan yang sangat baik. Hal ini diduga dosis pupuk kandang sapi 30 ton/ hadapat memenuhi jumlah kebutuhan unsur hara makro dan mikro serta dapat memperbaki sifat fisik tanah yaitu tekstur dan struktur tanah, sifat kimia tanah yaitu unsur makro (Nitrogen, Fosfor, Kalium, Magnesium, Kalsium dan Sulfur) dan mikro (Boron, Tembaga, Seng, Besi, Molibdenum, Mangan, Khlor, Natrium, Cobalt, Silicone dan Nikel) dan sifat biologi tanah yaitu aktivitas mikroorganisme tanah yang lebih baik sehingga dapat memak- simalkan fungsi nutrisi dalam proses pertumbuhan nilam. Pupuk kandang sapi menyediakan unsur-unsur hara esensial makro dan mikro yang diperlukan bagi pertumbuhan tanaman, sehingga tanaman dapat tumbuh lebih baik (Andalusia, 2005). Sesuai dengan pendapat Mulyani dan Kartasapoetra (1995) dalam Nugrahini (2013) bahwa pemberian pupuk kandang dapat meningkatkan kesuburan tanah, mempertinggi kadar humus, memperbaiki struktur tanah dan mendorong aktivitas mikroorganisme tanah. Dengan meningkatnya ketersediaan dan serapan unsur hara $\mathrm{N}, \mathrm{P}$ dan $\mathrm{K}$ dari hasil dekomposisi pupuk kandang sapi dapat memacu pertumbuhan vegetatif tanaman. Sesuai dengan pendapat Sarief (1986) dalam Nugrahini (2013) bahwa pertumbuhan vegetatif tanaman sangat membutuhkan unsur hara N, P dan K. Menurut Sutanto (2002) dalam Andalusia (2005), tanah yang kaya bahan organik mengakibatkan aerasi tanah lebih baik dan tidak mudah mengalami pemadatan daripada tanah yang mengandung bahan organik rendah. Selanjutnya Kononova (1966) dalam Andalusia (2005) menyatakan bahwa struktur tanah yang baik menyediakan kondisi yang baik pula dalam hal suplai air dan nutrisi ke tana- 
man. Dengan adanya perbaikan terhadap sifat-sifat tanah tersebut, maka tanaman dapat tumbuh baik.

\section{Interaksi antara lama perendaman} Rootone $\mathrm{F}$ dan dosis pupuk kandang sapi

Hasil penelitian menunjukan bahwa lama perendaman Rootone $\mathrm{F}$ dan dosis pupuk kandang sapi terdapat interaksi berbeda sangat nyata terhadap semua variabel. Kombinasi terbaik antara lama perendaman Rootone F selama 3 jam (L3) dengan dosis pupuk kandang sapi 30 ton/ha. Interaksi ini terjadi karena adanya saling mendukung antara fungsi dan peranan Rootone $F$ pada perendaman 3 jam secara optimal. IBA, IAA dan NAA yang terkandung dalam Rootone $F$ dapat mendorong perpanjangan, pembelahan sel, dan pembesaran sel, dengan dosis pupuk kandang sapi 30 ton/ha mampu memperbaiki sifat fisik, kimia dan biologi tanah secara optimal.

Tabel 4. Angka Rata-rata Analisis Statistik dan Interaksi Antara Lama Perendaman dan Dosis Pupuk Kandang variabel pengamatan.

\begin{tabular}{lllll}
\hline $\begin{array}{l}\text { Kombinasi } \\
\text { Perlakuan }\end{array}$ & $\begin{array}{l}\text { Diameter batang } \\
(\mathrm{mm})\end{array}$ & $\begin{array}{l}\text { Tinggi tanaman } \\
(\mathrm{cm})\end{array}$ & $\begin{array}{l}\text { Bobot basah } \\
\text { brangkasan } \\
(\mathrm{g})\end{array}$ & $\begin{array}{l}\text { Bobot kering } \\
\text { brangkasan } \\
(\mathrm{g})\end{array}$ \\
\hline L1D0 & $47,20 \mathrm{a}$ & $44,40 \mathrm{a}$ & $24.21 \mathrm{a}$ & $2.97 \mathrm{a}$ \\
L1D1 & $57,20 \mathrm{a}$ & $47,73 \mathrm{a}$ & $41.82 \mathrm{~b}$ & $6.18 \mathrm{a}$ \\
L1D2 & $61,93 \mathrm{~b}$ & $63,20 \mathrm{c}$ & $70.83 \mathrm{c}$ & $11.43 \mathrm{c}$ \\
L1D3 & $63,90 \mathrm{~b}$ & $67,87 \mathrm{~d}$ & $81.84 \mathrm{~d}$ & $13.42 \mathrm{c}$ \\
L2D0 & $58,93 \mathrm{a}$ & $47,93 \mathrm{a}$ & $27.79 \mathrm{a}$ & $3.83 \mathrm{a}$ \\
L2D1 & $55,87 \mathrm{a}$ & $50,73 \mathrm{~b}$ & $46.89 \mathrm{~b}$ & $7.11 \mathrm{~b}$ \\
L2D2 & $62,67 \mathrm{~b}$ & $65,40 \mathrm{c}$ & $70.30 \mathrm{c}$ & $15.08 \mathrm{c}$ \\
L2D3 & $64,33 \mathrm{c}$ & $67,87 \mathrm{~d}$ & $92.67 \mathrm{e}$ & $16.48 \mathrm{~d}$ \\
L3D0 & $60,93 \mathrm{~b}$ & $47,57 \mathrm{a}$ & $31.03 \mathrm{a}$ & $4.84 \mathrm{a}$ \\
L3D1 & $60,40 \mathrm{a}$ & $52,87 \mathrm{~b}$ & $48.83 \mathrm{~b}$ & $7.74 \mathrm{~b}$ \\
L3D2 & $62,53 \mathrm{~b}$ & $66,93 \mathrm{c}$ & $75.48 \mathrm{c}$ & $16.41 \mathrm{~d}$ \\
L3D3 & $67,87 \mathrm{c}$ & $68,33 \mathrm{~d}$ & $100.31 \mathrm{e}$ & $20.57 \mathrm{e}$ \\
F Hitung & $10,69 * *$ & $4,66{ }^{* *}$ & $7,21 * *$ & $9,05 *$ \\
F Tabel 5 \% & 2,55 & 2,55 & 2,55 & 2,55 \\
F Tabel 1 \% & 3,76 & 3,76 & 3,76 & 3,76 \\
BNT 5 \% & 3,85 & 4,54 & 10,54 & 4,05 \\
KK & $3,78 \%$ & $4,66 \%$ & $10,49 \%$ & $22,78 \%$ \\
\hline K & & & &
\end{tabular}

Keterangan:

Angka-angka dalam kolom dan perlakuan yang diikuti dengan huruf yang sama menunjukkan tidak berbeda nyata berdasarkan Uji BNT pada taraf $5 \% .{ }^{* *}=$ berbeda sangat nyata, ${ }^{*}=$ berbeda nyata, tn $=$ tidak berbeda nyata.

Menurut Sarief (2002) peranan pupuk kandang adalah dapat memperbaiki sifat fisik, kimia dan biologi tanah, meningkatkan kemampuan untuk menyerap air, kapasitas tukar kation, sebagai sumber hara, memperbaiki suhu tanah dan aerasi. Proses pembelahan, pemanjangan dan differensiasi sel pada tanaman tergantung kondisi tanah tempat tanaman tumbuh. Apabila laju pembelahan dan pemanjangan sel serta pembentukan jaringan berjalan cepat, maka pertumbuhan akar, batang dan daun juga akan cepat (Hidyanto dkk.,2003 dalam Fanesa, 2011). Lama perendaman 3 jam mendapat kan hasil terbaik yang dapat mendorong proses pertumbuhan stek tanaman nilam. Salah satu fungsi dan peranan IBA, IAA dan NAA yang terkandung dalam Rootone $F$ yaitu mendorong pembentukan, pembelahan sel dan pembentukan akar sehingga dapat membantu proses pertumbuhan tanaman nilam, dengan penambahan dosis pupuk kandang 30 ton/ha, maka unsur hara akan tersedia bagi tanaman dengan lingkungan pertanaman yang menguntungkan, akibatnya tanaman dapat menyerap unsur hara dengan maksimal.

Gardner dkk., (1991) menyatakan bahwa pertumbuhan vegetatif tanaman seperti akar, batang dan daun yang didukung oleh tersedianya unsur hara dalam jumlah cukup dan seimbang dapat mendorong me- 
ningkatnya kandungan karbohidrat di dalam tanaman. Karbohidrat dihasilkan dari prosesproses yang terjadi pada daun yaitu proses fotosintesis dan adanya proses metabolisme yang meningkat, sehingga seiring meningkatnya kandungan fotosintat di dalam tanaman pada fase vegetatif akan berpengaruh terhadap pertumbuhan tanaman nilam.

\section{KESIMPULAN}

1. Lama perendaman Rootone $F$ berpengaruh sangat nyata terhadap variabel jumlah akar, panjang akar terpanjang, boobot basah akar, bobot kering akar, diameter batang, bobot basah brangkasan, bobot kering brangkasan dan berpengaruh nyata terhadap variabel jumlah daun dan tinggi tanaman. Lama perendaman terbaik yaitu 3 jam (L3).

2 Dosis pupuk kandang sapi berpengaruh sangat nyata terhadap semua variabel yang diamati. Dosis pupuk kandang sapi terbaik yaitu 30 ton/ha (D3), (masih bersifat linier).

3. Interaksi antara lama perendaman Rootone $\mathrm{F}$ dan dosis pupuk kandang sapi berpengaruh sangat nyata terhadap semua variabel yang diamati. Interaksi terbaik pada lama perendaman Rootone F 3 jam dengan dosis pupuk kandang sapi 30 ton/ha (L3D3).

\section{DAFTAR PUSTAKA}

Anang, E. B., K. Badami, dan A. Arsyadmunir, 2013. Pengaruh Kombinasi Macam Zpt dengan Lama Perendaman Yang Berbeda terhadap Keberhasilan Pembibitan Sirih Merah (Piper Crocatum Ruiz \& Pav) Secara Stek. Fakultas Pertanian. Universitas Trunojoyo Madura. Madura. Vol. VI. No. 2.

Andalusia. 2005. Pengaruh Media Tanam dan Pupuk $N$ terhadap Pertumbuhan Bibit Jati Belanda (Guazuma Ulmifolia Lamk.). Institut Pertanian Bogor, Bogor.

Asnani. 2008. Pengaruh Jenis Tanah dan Dosis Pupuk Kandang Terhadap Pertumbuhan Setek Nilam
(Pogostemon cablin, Benth). Skripsi S1. UNS Press. Surakarta.

Fanesa, A. 2011. Pengaruh Pemberian Beberapa Zat Pengatur Tumbuh terhadap Pertumbuhan Stek Pucuk Jeruk Kacang (Citrus nobilis L.). Fakultas Pertanian Unand.

Gardner, F.P., R.B. Pearce, and R.L. Mitchell. 1991. Fisiologi Tanaman Budidaya. Terjemahan. UI Press. Jakarta. 424 hal.

Kusumo, S. 1994. Zat Pengatur Tumbuh Tanaman. Yasaguna, Jakarta.

Nugrahini. 2013. Respon Pertumbuhan Stek Tanaman Panili (Vanilla planifolia) terhadap Pemberian $\mathrm{Pu}$ puk Kandang Ayam dan Pupuk Organik Cair Nasa. Jurnal. Universitas Widyagama Mahakam Samarinda. Vol. V. No. 1, Samarinda.

Rotinsulu, dan M.Johan. 2008. Tehnik Budidaya Jelutung, Galam dan Ramin. Universitas Palangkaraya.

Rukmana, R. 2004. Nilam Prospek Agribisnis dan Teknik Budidaya. Kanisius, Yogyakarta.

Santoso, B.H. 1990. Nilam Bahan Industri Wewangian. Kanisius, Yogyakarta.

Sarief, ES. 2002. Kesuburan dan Pemupukan Tanaman Pertanian. Pustaka Buana. Jakarta.

Sudrajat, H. dan H. Widodo. 2011. Pengaruh Konsentrasi dan Lama Perendaman Rootone $F$ pada Pertumbuhan Pule Pandak (Rauwolfia Serpentina Benth). Universitas Trunojoyo, Surakarta.

Suprianto dan K. E. Prakasa. 2011. Pengaruh Zat Pengatur Tumbuh Rootone F Terhadap Pertumbuhan Stek Duabanga mollucana. Blume. Fakultas Kehutanan IPB. Bogor. Vol. 03 No. 01 Agustus 2011, Hal. 59 65. 